\title{
FINANCIAL DISTRESS PREDICTION IN SUBFRASTRUCTURE, UTILITY AND TRANSPORTATION SUB SECTOR SERVICES IN INDONESIA
}

\author{
Resa Meita Ary Putri \\ Faculty of Economics and Business, University of Jember \\ resa.meita@gmail.com \\ Hadi Paramu \\ Faculty of Economics and Business, University of Jember \\ hadi.feb@unej.ac.id \\ Intan Nurul Awwaliyah \\ Faculty of Economics and Business, University of Jember \\ In.awwaliyah.feb@unej.ac.id
}

Received: January, 2020; Accepted: May, 2020; Published: September, 2020 DOI: https://doi.org/10.24123/jmb.v19i2

\begin{abstract}
The purpose of this study is to examine and analyze whether profitability ratios, liquidity ratios, solvency ratios, cash flow ratios, activity ratios, and cash positions affect the financial distress in service companies in infrastructure, utilities, and transportation sub-sectors in Indonesia. The number of samples of this study are 51 companies and research ranges from 2013-2018. Total observations in this study are 289 out of 306 observations, and the rest are outliers. The method of analysis is using logistic regression analysis. The result shows there are two independent variables ( Cash Flow from Operations to Total Assets and Cash to Current Liabilities ) that have a significant effect on financial distress, while four independent variables ( Return on Equity, Working Capital to Total Assets, Debt Assets Ratio, Sales to Current Assets ) have no significant effect on financial distress.
\end{abstract}

Keywords: financial distress, financial ratios, logistic regression, service companies

\begin{abstract}
Abstrak
Tujuan penelitian ini yaitu untuk menguji dan menganalisis apakah rasio profitabilitas, rasio likuiditas, rasio solvabilitas, rasio arus kas, rasio aktivitas, dan posisi kas berpengaruh terhadap financial distress pada perusahaan jasa sub sektor infrastruktur, utilitas, dan transportasi di Indonesia. Jumlah sampel penelitian ini sebanyak 51 perusahaan dan rentang penelitian dari tahun 2013-2018. Total pengamatan dalam periode penelitian sebanyak 289 pengamatan dari 306 pengamatan, sisanya merupakan data outlier. Metode analisis menggunakan analisis regresi logistik dengan hasil penelitian yaitu dua variabel independen (CFO/TA dan Cash/CL) yang berpengaruh signifikan terhadap financial distress, sedangkan empat variabel independen (ROE, WCTA, DAR, Sales/CA) tidak berpengaruh signifikan terhadap financial distress perusahaan.
\end{abstract}

Kata Kunci: financial distress, rasio keuangan, regresi logistik, perusahaan jasa 


\section{INTRODUCTION}

Tension of trade relations and a number of geopolitical risks between the United States that continues to add pressure to the volume of trade and world economic growth. The weakening of the global economy also has an impact on the domestic economy. This can be seen from industry data and trade in the global market which tends to weaken. The Statistics Indonesia (Badan Pusat Statistik- BPS) noted a slowdown in economic growth in the first half of 2019 , which amounted to $5.06 \%$. This realization experienced a slowdown from economic growth in the first half of 2018, which amounted to $5.17 \%$. Slowing national economic growth has an impact on industrial growth in various sectors in Indonesia. Slowing economic growth and trade competition will lead to tighter competition. This condition becomes concern to investors and creditors to the company's financial condition which can lead to bankruptcy.

Platt \& Platt (2002) states that the financial distress is a stage of decline in the company's financial condition before it reaches the bankruptcy or liquidation. One indicator that can be used as a criterion is the company's negative net profit for two consecutive years or more (Almilia \& Kristijadi 2003). A total of 22 (twenty-two) companies experienced negative net profit for two consecutive years or more. In fact, there were 9 (nine) companies that experienced negative net profit for four consecutive years, namely one energy sub-sector company, two telecommunications sub-sector companies, and six transportation sub-sector companies. This shows that the service companies in the Infrastructure, Utilities and Transportation sectors over the past four years have experienced financial distress.

There are several factors that can affect a company's financial distress. These factors are profitability, liquidity, solvency, and company activities. Nurhayati et al., (2017), Widarjo \& Setiawan (2009) state that the profitability ratio had a significant negative effect on financial distress. Whereas Vieira et al. (2013) states that profitability ratios are not a good predictor of financial distress. The liquidity ratio has a negative influence on financial distress on the results of Platt \& Platt's research (2002), in contrast to the results of Matturungan et al. (2017) which shows that the liquidity ratio has a positive effect on financial distress. According to Widarjo \& Setiawan (2009) leverage ratios does not effect on financial distress, whereas according to Hapsari (2012) leverage has a significant negative effect on financial distress. Adi \& Rahmawati (2013) states that cash flow from operating to total assets has an effect but it is not significant, different from the results of Kordestani et al. (2011) which states that cash flow affects the company's financial distress.

Based on several previous studies on financial distress, there are differences that still can be found in results related to the prediction of financial distress companies, so there are still gaps that can be reviewed using the latest data and different companies. This study uses service companies in the Infrastructure, Utilities and Transportation sectors because most companies in the sector have negative net profits (Platt \& Platt 2002; Almilia \& Kristijadi 2003). So that, the possibility of the service sector sub-sector experiencing financial distress is quite high.

The use of financial statements as data in this study and does not include the company's performance in the capital market. It does due to the right financial statements show more real performance of the company in using the assets to result in profit, so if a company's performance is good, it will automatically affect the company's stock price, and vice versa.

This study analyzes the data on the company's financial statements as far as 
before and two years before whether it can predict the company's financial distress and as an early warning in the current period or afterwards. This research is conducted with four years of observation. Therefore, this research analyzes the determinants of financial distress in service companies in Indonesia, with the independent variable used is financial ratios. Financial ratios are used, i.e the ratio of profitability, liquidity ratio, solvency ratio, the ratio of cash flow, activity ratios and cash position.

Profitability is a ratio that measures the effectiveness management has in generating company profits (Yadiati 2017). The higher the profits obtained, then there is the possibility of funds that are unemployed or not used company funds as needed. Return on equity (ROE) is a measurement of the income available to company owners (both ordinary shareholders and preferred stockholders) for the capital they invest. The higher the value of ROE, the higher the level of profits generated (Suwarno 2004), then the possibility of companies experiencing financial distress is lower. Good company growth will provide information to stakeholders that the company has been able to maintain its continuity and can grow. High company growth will indicate that the company is in good health and not in a state of financial distress. Widati \& Pratama (2013) conducted a study of 192 manufacturing companies listed on the Indonesia Stock Exchange showing the results that ROE has a significant effect on financial distress. Restianti \& Agustina's research (2018) used a total of 105 types of companies, showing ROE results had a significant negative effect. This means the company's growth is in a healthy state and not in a state of financial distress. The research by Wongsosudono \& Chrissa (2013), Haq et al. (2013), and Hazeem \& Alaa (2012) also showed that ROE affect the financial distress of the company.

Liquidity shows the company's ability to fund the company's operations and pay off the company's short-term obligations. Liquidity is proxied using working capital to total assets (WCTA). This ratio shows the company's ability to generate net working capital from all total assets owned by the company (Rahmawati \& Hadiprajitno 2015). The results of Alifiah \& Tahir's research (2018) on trade and service sector companies in Malaysia showed that working capital to total assets ratio had a significant negative effect on financial distress. This means that the higher the ratio of working capital to total assets, the less likely the company is experiencing financial distress. The results examined the relationship between working capital and company profitability across countries with different levels of industry. This study reveals that there is a strong negative relationship between profitability, measured through net operating profit. Lakshan \& Wijekoon (2013) examined using 70 bankrupt companies and 70 nonbankrupt companies listed on the Colombo capital market in the period 2002-2008 showing working capital to total assets affected the financial distress of companies both bankrupt and not. Research conducted by Darmawan \& Supriyanto (2018), Delavar et al. (2015), Caballero et al (2014), and Matturungan et al. (2017) also show the results that working capital to total assets affects the company's financial distress.

The solvency ratio shows the company is managing to fulfill all its obligations, both short term and long term. This ratio can be used as a proxy for debt to asset ratios. A high debt to asset ratio means that most assets are financed by debt. The greater the burden of the company to cover the obligations and interest charged to the company which will trigger financial distress. Research Vieira et al. (2013) used 150 companies that went bankrupt and 150 companies did not go bankrupt and showed the result that the DAR ratio had a positive effect. This means that the higher the DAR value, the higher the possibility of the company experiencing financial distress. Ribeiro (2011) instead of Vieira et al. (2013) examined how to anticipate the failure of companies in the wood furniture industry by using multivariate discriminant analysis 
and logistic analysis. The results showed a positive relationship between debt ratio and financial distress. The use of debt by the company will affect the level of risk of the company. The higher the use of debt, the higher the level of risk of companies experiencing financial distress (Fitriyah \& Hariyati (2013). Research Nurhayati et al. (2017), Rida \& Khafid (2014), Meilinda \& Muharam (2012), Thim et al. (2011) also showed that DAR affects the company's financial distress.

Cash flow analysis can be used to detect companies that are experiencing financial difficulties and have the possibility of not being able to pay obligations or operating costs even though the company generates high profits (Sari \& Utami 2009). The results of research conducted by Sari \& Utami (2009) show that CFO / TA significantly influences the company's financial distress. An increased cash flow ratio will increase profits and decrease the possibility of financial distress (Almilia 2006). Sayari \& Mugan (2013) suggested that the components in the cash flow statement contain relevant information in identifying financial health or deterioration in the company. Research conducted by Ong et al. (2011) uses public company objects listed on Bursa Malaysia and classified as financial distress companies from 20012008. The results showed a significant influence between the ratio of cash flows to the company's financial distress. Ibarra (2009) conducted a study on the performance of manufacturing firms in the Philippines and the result showed the cash flow could be used to evaluate the financial position of manufacturing companies. Research conducted by Kamaluddin et al. (2019), and Ahmad et al. (2010) also showed that the current cash operations affect the financial distress of the company.

The activity ratio reflects how much a company's ability to use its assets for corporate management purposes. Activity ratio measures the ability of management in dealing with competitive conditions (Almansour 2015). Almansour's research results (2015) showed that the activity ratio has an influence on the company's financial distress. The activity ratio reflects how much a company's ability to use its assets for corporate management purposes. If the company is not able to maximize the use of company assets, the company's sales will also not be maximized. This will bring the company closer to financial distress. Research conducted by Wah et al. (2001) showed that activity flow ratios can be used as predictors of whether a company experiences financial distress or not.

Cash positions are a sign of financial strength and liquidity. Cash positions represent the amount of cash that a company, investment fund or bank has in its books. Cash position shows the company's cash level of expenses and liabilities. A stable cash position is a position that shows a company to cover current liabilities with cash and current assets. Minnery (2006) argues that although there are companies that are declared as profitable businesses but do not have enough cash, the company will eventually experience liquidity problems. Atieh (2014) conducted research on six major pharmaceutical companies in Jordan in the 2007-2012 period and stated that a strong and good cash position showed that the company was able to pay its obligations and the low possibility of experiencing financial distress.

Companies that experience financial distress conditions can be known by studying financial performance in financial statements issued by the company. Financial ratios are used as a tool to determine whether a company is in financial distress. A framework of thought is useful for giving direction to ways of thinking and studying problems. The following is a framework of thought used in this study. 


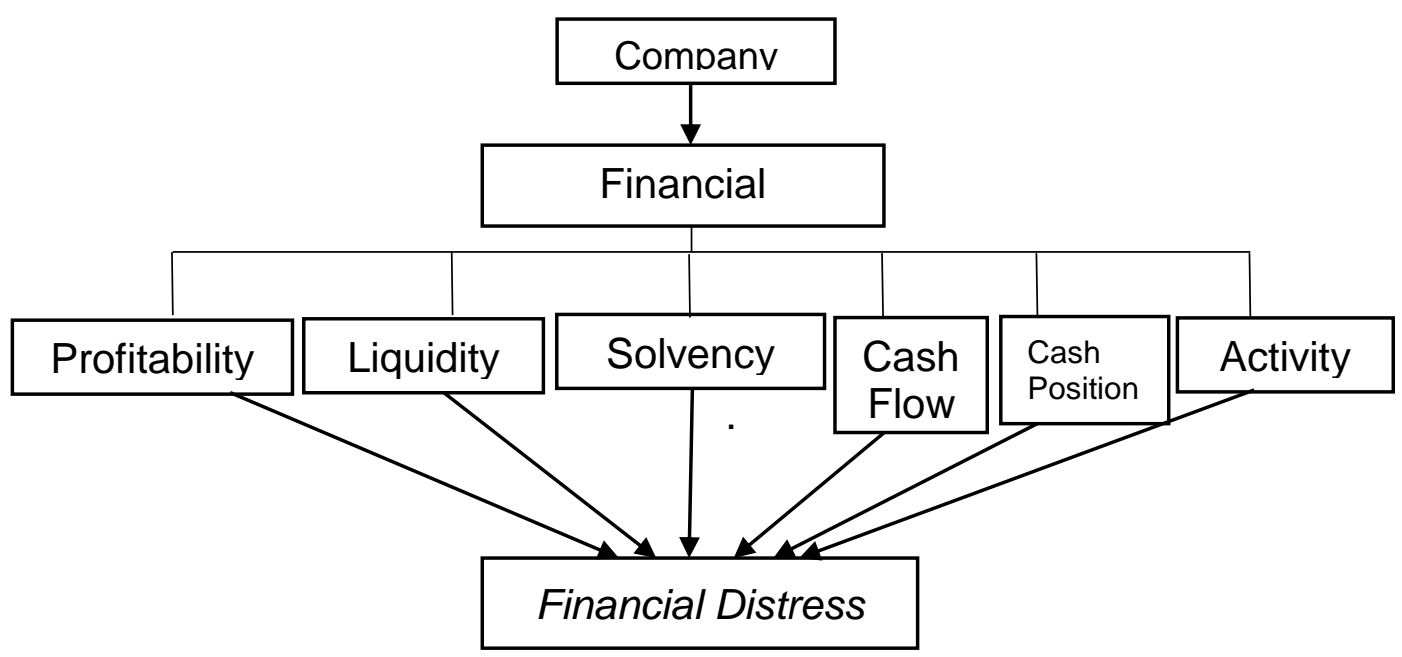

Figure 1. Conceptual Framework

\section{RESEARCH METHODS}

The population in this study was the infrastructure, utilities and transportation sub-sector service companies listed on the Indonesia Stock Exchange during the 2013-2018 period. There were 51 companies based on the following criteria determined in this study, namely companies that did not experience delisting during the research year and companies that published complete annual financial statements. This criterion was used to ensure the completeness of the data needed.

Table 1 presents the measurement variables used in this study. All variables are ratio scales except for financial distress measured on a nominal scale

Table 1. Operational Definitions and Variable Measurement Scale

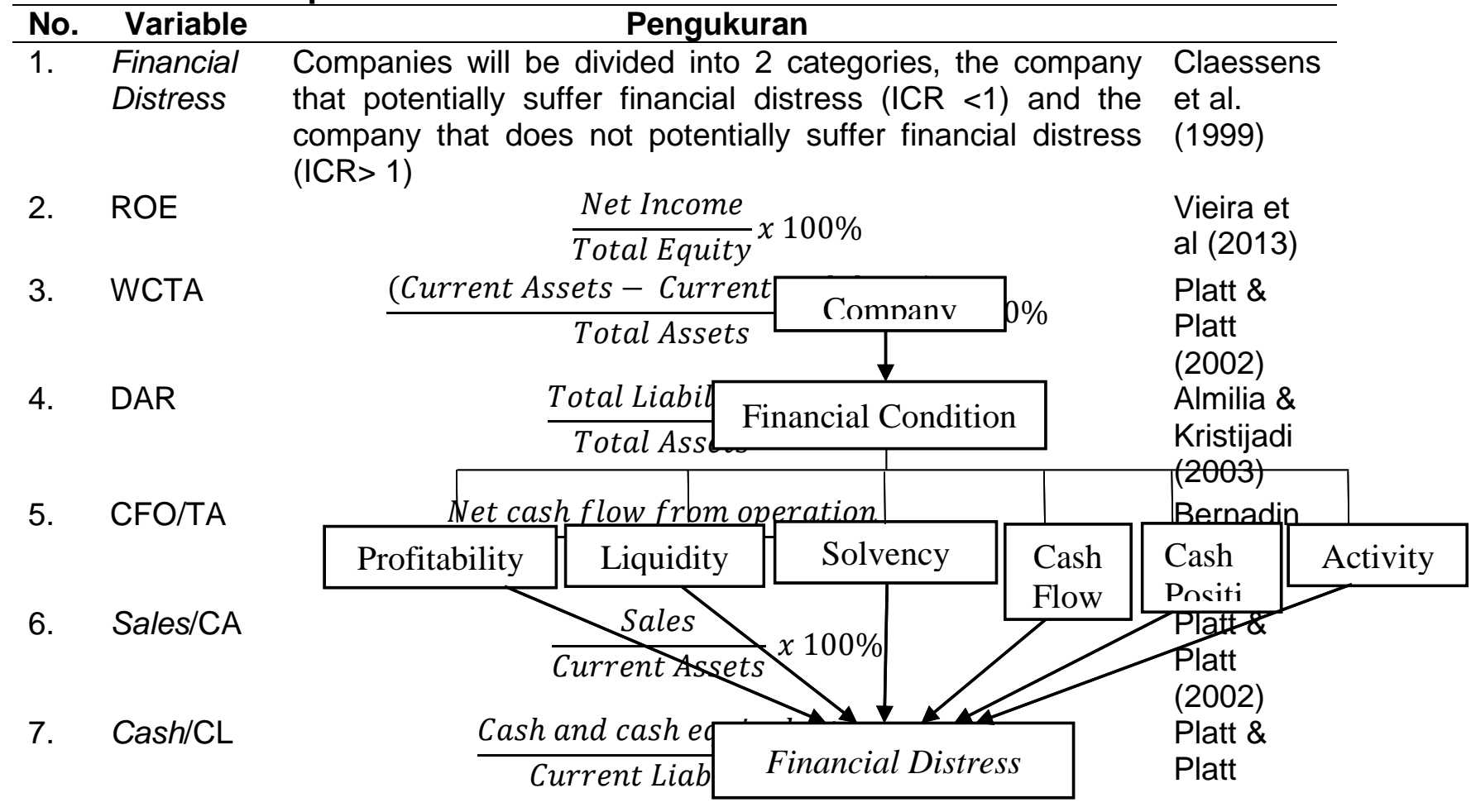


(2002)

This study modified the model using data one year before $(\mathrm{t}-1)$ to predict financial distress of company $\mathrm{i}$ in the $\mathrm{t}$ year for Model 1 , and using data one year before $(\mathrm{t}-1)$ and data two years before ( $\mathrm{t}-2$ ) to predict the financial distress of company $\mathrm{i}$ in the $\mathrm{t}$ year for Model 2.

$$
\begin{aligned}
& F D_{i t}=b_{0}+b_{1} R_{0} E_{i t-1}+b_{2} W_{C T A} i t-1+b_{3} D_{A R} \text { it-1 }+b_{4} \text { CFO/TA } i t-1 \\
& +b_{5} \text { Sales } / \mathrm{CA}_{\mathrm{it}-1}+\mathrm{b}_{6} \text { Cash/CL it-1 + } \mathrm{e}_{\mathrm{i}} \\
& F_{i t}=b_{0}+b_{1} R E_{i t-1}+b_{2} R E_{i t-2}+b_{3} W_{C T A} i t-1+b_{4} W_{C T A} i t-2+b_{5} D_{i t-1} \\
& +b_{6} \mathrm{DAR}_{\mathrm{it}-2}+\mathrm{b}_{7} \text { CFO/TA } \mathrm{it}_{-1}+\mathrm{b}_{8} \text { CFO/TA } \mathrm{A}_{\mathrm{it}-2}+\mathrm{b}_{9} \text { Sales/CA } / \mathrm{A}_{\mathrm{it}-1} \\
& +b_{10} \text { Sales } / C A_{i t-2}+b_{11} \text { Cash/CL } i t-1+b_{12} \text { Cash/CL it-2 }+e_{i}
\end{aligned}
$$

Hypothesis Formulation

$\mathrm{H} 1$ : Return on Equity (ROE) affects financial distress

H2: Working Capital to Total Assets (WCTA) affects financial distress

H3: Debt to Assets Ratio (DAR) affects financial distress

H4: Cash flow from operations to total assets influences financial distress

H5: Sales to current assets affect financial distress

H6: Cash to Current Liabilities affects financial distress

\section{RESULT AND DISCUSSIONS}

Data checking is performed to determine whether there are outlier data in this study. Statistically, outlier data can be detected using the z-score value of each observation data. The results showed that there were 17 outlier data and were

\begin{tabular}{|c|c|c|c|c|c|c|}
\hline & ROE & WCTA & DAR & CFO / TA & Sales / C A & Cash / CL \\
\hline \multicolumn{7}{|l|}{ Panel A. All Samples } \\
\hline Minimum & -423.21 & -353.83 & 0 & -17.63 & -13500 & 0.02 \\
\hline Maximum & 546.98 & 87.53 & 418000 & 30.27 & 4464.08 & 1011.68 \\
\hline Average & 46,034 & -11.7 & 1684,9 & 7.39 & 204.32 & 48.91 \\
\hline $\begin{array}{l}\text { Standard Deviation } \\
\text { Variation }\end{array}$ & 65.37 & 48.29 & 24789,4 & 7.59 & 869.4 & 88.95 \\
\hline Coefficient & 1.42 & $-4,13$ & 14.71 & 1.03 & 4.26 & 1.82 \\
\hline \multicolumn{7}{|c|}{ Panel B. Non-Financial Distress Companies } \\
\hline Minimum & -423.21 & -353.83 & 0.03 & $-10,25$ & 0.08 & 0.02 \\
\hline Maximum & 61.17 & 87.53 & 649.9 & 30.27 & 4464.08 & 1011.68 \\
\hline Average & 89,379 & -4.94 & 59,15 & 10,23 & 284,57 & 71.35 \\
\hline Standard Deviation & 42.08 & 50.77 & 67.41 & 7.71 & 405.49 & 113.17 \\
\hline
\end{tabular}
excluded from the observation data on the basis of obtaining better research results. Table 2 presents the descriptive statistics of the variables in this study.

Table 2. Descriptive Statistics of All Samples of Companies, Non-Financial Distress Companies, and Financial Distress Companies 


\begin{tabular}{lcccccc} 
Variation & \multicolumn{7}{c}{} & & & \\
Coefficient & 0.47 & $-10,28$ & 1.14 & 0.75 & 1.42 & 1.59 \\
\hline Panel C. Financial Distress Companies & & & & \\
Minimum & -264.26 & $-314,53$ & 0 & -17.63 & -13500 & 0.04 \\
Maximum & 546.98 & 32.24 & 418000 & 22.58 & 1634.89 & 393.88 \\
Average & .779 & -17.65 & 3119,4 & 4.88 & 133.52 & 29.1 \\
Standard Deviation & 80.48 & 45.32 & 33998,2 & 6.55 & 1127,59 & 52.98 \\
Variation & & & & & & \\
Coefficient & 103.31 & -2.57 & 10,90 & 1.34 & 8.45 & 1.82 \\
\hline
\end{tabular}

Table 3. Model 1 and Model 2 Logistic Regression Results

\begin{tabular}{|c|c|c|c|c|c|c|}
\hline \multirow[b]{2}{*}{ Variable } & \multicolumn{4}{|c|}{ Model 1} & \multicolumn{2}{|c|}{ Model 2} \\
\hline & $\begin{array}{c}\text { Regression } \\
\text { Coefficient }\end{array}$ & Wald & $\begin{array}{c}\text { Level of } \\
\text { Significance }\end{array}$ & $\begin{array}{c}\text { Regression } \\
\text { Coefficient }\end{array}$ & Wald & $\begin{array}{l}\text { Regression } \\
\text { Coefficient }\end{array}$ \\
\hline $\operatorname{ROE}_{\mathrm{IT}-1}$ & $-0,001 \mathrm{~ns}$ & .147 & 0701 & $-0,0006 \mathrm{~ns}$ & 0.046 & 0,830 \\
\hline $\operatorname{ROE}_{\mathrm{IT-2}}$ & & & & $-0.005 \mathrm{~ns}$ & 1,485 & 0,223 \\
\hline WCTA $_{i t-1}$ & $0.003^{n s}$ & .459 & .498 & $0.004 \mathrm{~ns}$ & 0.767 & .381 \\
\hline WCTA $_{\text {it-2 }}$ & & & & $-0.004 \mathrm{~ns}$ & 0.602 & 0.438 \\
\hline $\mathrm{DAR}_{\text {IT-1 }}$ & $0,0001 \mathrm{~ns}$ & 0,700 & .403 & $0,0001 \mathrm{~ns}$ & 0.616 & 0.433 \\
\hline DAR2 ${ }_{i t-2}$ & & & & 0,0001 ns & .321 & 0.571 \\
\hline $\begin{array}{l}\text { CFO / } \\
\text { TA }_{i t-1}\end{array}$ & $-0,070 \cdots$ & 7,350 & 0.007 & $-0,078 \cdots$ & 7,804 & 0.005 \\
\hline & & & & $0.057^{*}$ & 3,858 & 0.050 \\
\hline Sales / & $0.001 \mathrm{~ns}$ & 0.866 & .352 & 0.057 ts & .491 & .484 \\
\hline $\begin{array}{l}\text { Sales / } \\
\mathrm{CA}_{i t-2}\end{array}$ & & & & $-0,0009 \mathrm{~ns}$ & 1,663 & .197 \\
\hline Cash / & $-0.01 \cdots$ & 6,839 & 0.009 & $-0,010$ & 6,462 & 0.011 \\
\hline $\begin{array}{l}\text { Cash / } \\
\mathrm{CL}_{\mathrm{it}-2}\end{array}$ & & & & $0.015^{\ldots}$ & 8.265 & 0.004 \\
\hline $\begin{array}{l}\text { A } \\
\text { constant }\end{array}$ & 1,215 & 10,193 & .001 & $-0,182$ & 0.127 & 0.015 \\
\hline
\end{tabular}

Note: ${ }^{* *},{ }^{* *}=$ significant at $\alpha 5 \%, 1 \%$; ts $=$ insignificant

Table 4. Test results for Hosmer and Lemeshow's Goodness of Fit Test of Model 1 and Model 2

\begin{tabular}{lcc}
\hline Information & Chi-square & Level of Significance \\
\hline Model 1 & 8,692 & .369 \\
Model 2 & 3,498 & 0.899 \\
\hline
\end{tabular}

The feasibility of the logistics model can be tested using Hosmer and Lemeshow's Goodness of Fit Test. A model is considered feasible if the statistical value of the Hosmer and Lemeshow's Goodness of Fit Test is greater than $5 \%$. Hosmer and Lemeshow's statistics show Chi-Square values from Model $1(p=8,692)$ and Model $2(p=3,498)$ which are greater than $5 \%$. This means that Model 1 and Model 2 match the data and can predict the value of observations. 
Value Nagelkerke $\mathrm{R}$ Square shows the percentage of the variability of independent variables in explaining financial distress. Statistical test results show the value of Nagelkerke R Square Model 1 and Model 2 that is equal to 0.20 and 0.36 . This means that the dependent variables which can be explained by the independent variables (ROE, WCTA, DAR, CFO / TA, Sales / CA, and Cash / CL) for Model 1 and Model 2 are $20 \%$ and $35 \%$.

The $2 \times 2$ classification test calculates the estimated number of observations that are true and false with the total observations classified correctly by the model. The predicted accuracy of Model 1 and Model 2 is good because the accuracy value is more than $50 \%$. The results of the $2 \times 2$ classification are presented in Table 5.

Table 5. Classification Test Results for 2x2 Model 1 and Model 2

\begin{tabular}{lccc}
\hline \multicolumn{1}{c}{ Information } & \multicolumn{3}{c}{ Prediction } \\
\cline { 2 - 4 } & $\begin{array}{c}\text { No Financial } \\
\text { Distress }\end{array}$ & $\begin{array}{c}\text { Financial } \\
\text { Distress }\end{array}$ & $\begin{array}{c}\text { Accuracy of } \\
\text { Classification }\end{array}$ \\
\hline Panel A. Model 1 & 50 & 29 & $63.3 \%$ \\
No Financial Distress & 23 & 56 & $70.9 \%$ \\
Financial Distress & & & $67.1 \%$ \\
\hline Percentage (\%) Overall & 62 & 17 & $78.5 \%$ \\
\hline Panel A. Model 2 & 24 & 55 & $69.6 \%$ \\
No Financial Distress & & & $74.1 \%$ \\
Financial Distress & & &
\end{tabular}

Based on statistical tests for the overall suitability model, the results consistently show that the logistic regression model fits the research data and it is able to predict observations. This study found that there were two significant independent variables, namely CFO / TA and Cash / CL.

The CFO / TA regression coefficient is negative and significant, so $\mathrm{H} 4$ is accepted. The negative regression coefficient shows that the higher the CFO / TA of the company, the lower the risk of the company experiencing financial difficulties. CFO / TA shows that the company has a good performance in its operations and the company can use it to generate revenue. If the cash flow from operations increases, the financial health of the company also increases, whereas if the cash flow from operations decreases, it is possible for companies to use debt to pay for investment plans (Sayari \& Mugan 2013). Transportation sector companies have lower average CFO / TA than other sectors. This is due to the rapid development of technology that makes transportation companies able to increase market share and company revenue. The slowdown in the domestic economy due to the trade war also affects transportation companies that depend on trade supply chains between China and the United States.

The disruption of the company's operational system can certainly affect the amount of cash inflows that are less than the amount of cash issued by the company due to operational expenses that remain to be paid. The lack of cash inflows will put the company in trouble paying suppliers, employees, purchasing supplies, or paying off other obligations. This can lead to the possibility of companies to increase funding in the form of loans which can lead to the possibility of higher financial distress. Conversely, if the company is able to carry out its operational activities well and 
generate greater revenue, then the company can pay operating expenses and other obligations and have sufficient cash to be used in subsequent operational activities. The results of this study support the research of Almilia (2006) and Vieira et al. (2013).

The results of this study also found that Cash / CL is significant, so $\mathrm{H} 6$ is accepted. The negative regression coefficient indicates that the higher the Cash / CL of the company, the lower the risk of the company experiencing financial difficulties. The analysis shows that the average value of Cash / CL is positive in several companies both companies that have financial and non-financial difficulties. This indicates the company has a good cash position. Companies with good performance and optimal company operations will get enough or more revenue. The income can be used to cover company obligations and the company still has cash left over or the company has a positive cash position. The opposite, if the company's performance is poor or makes a large investment without careful preparation of a strategy, the company may record positive but low cash positions or negative cash positions. A negative cash position indicates that the company does not have enough funds to cover the investment costs. This condition can deteriorate at the level of the company being unable to get funding sources and then causing financial distress. The results of this study are in line with research conducted by Platt \& Platt (2002), Almilia \& Kritijadi (2003) which state that Cash / CL cannot be used to predict corporate financial pressures.

The results of the independent variables ROE, WCTA, DAR, and Sales / CA are not consistent with Almilia \& Kristijadi (2003), Lakshan \& Wijekoon (2013), Nurhayati et al. (2017), and Restianti \& Agustina (2018). However, the results of this study are in line with research conducted by Platt \& Platt (2002), Vieira et al. (2013), and Rahmawati \& Hadiprajitno (2015).

There were several limitations in this study. First, the difficulty of access and availability of data. It happened because of the right of some companies which had a policy not to publish financial statements or annual report on the company's official web site if it has passed through three years or more. Second, the companies that were made into objects were service companies in the infrastructure, utilities, and transportation sectors listed on the IDX.

\section{CONCLUSSION}

This study aims to test and analyze whether profitability ratios (Return on Equity), liabilities (Working Capital to Total Assets ), solvency (Debt to Asset Ratio ), cash flow (Cash Flow from Operations to Total Assets ), activities (Sales to Current assets ) and cash position (cash to Current Liabilities ) affecting the financial difficulties in the sub-sector corporate services infrastructure, utilities and transportation in Indonesia. The method used is logistic regression. The results showed that not all ratios had the same prediction results. The cash flow ratio and cash position are empirically influential and can be used to predict the company's financial distress.

This study concludes that CFO / TA and Cash / CL can be used to detect financial distress in service companies in Indonesia, especially in the infrastructure, utilities, and transportation sectors. The research conducted is expected to help any party involved in the company.

Referring to the limitations of the study, it is expected in future studies to use the object of both registered and service companies that are not listed on the Indonesia Stock Exchange, as well as the use of more variation ratios to get a better prediction model and predictive ability.

\section{ACKNOWLEDGMENTS}


Feel free to impress your gratitude to person(s) that help you in accomplish the research. Please keep the paragraph not more than 200 words.

\section{REFERENCES}

Adi, S. W., Rahmawati, A. I. E. (2013). Analisis Rasio Keuangan Terhadap Kondisi Financial distress pada Perusahaan Manufaktur yang Terdaftar di Bursa Efek Indonesia Tahun 2008-2013. Seminar Nasional dan the 2nd Call for Syariah Paper, 5(2): 315-326.

Ahmad, A., Azhar Z., \& Wan-Abu-Bakar W. (2010). Cash-Flows Ratios as Predictors of Corporate Failure. IEE Symposium on Industrial Electronics and Applications, 255258.

Alifiah, M. N., Tahir, M. S. (2018). Predicting Financial Distress Companies in the Manufacturing and Non-Manufacturing Sectors in Malaysia Using Macroeconomic Variables. Management Science Letters, 8, 593-604.

Almansour, B. Y. (2015). Empirical Model for Predicting Financial Failure. American Journal of Economics, 1(3):113-24.

Almilia, L. S. (2006). Prediksi Kondisi Financial Distress Perusahaan Go-Public dengan Menggunakan Analisis Multinomial Logit. Jurnal Ekonomi dan Bisnis, 12(1):1-26.

Almilia, L. S., Kristijadi. (2003). Analisis Rasio Keuangan untuk Memprediksi Kondisi Financial Distress Perusahaan Manufaktur yang Terdaftar di Bursa Efek Jakarta. Jurnal Akuntansi dan Auditing Indonesia, 7(2), 183-210.

Atieh, S. H. (2014). Liquidity Analysis Using Cash Flow Ratios as Compared to Traditional Ratios in the Pharmaceutical Sector in Jordan. International Journal of Financial Research, 5(3), 146-158.

Bernadin, D. E. Y., Tifani, T. (2019). Financial Distress Predicted by Cash Flow and Leverage with Capital Intensity as Moderating. E-Journal Apresiasi Ekonomi, 7(1), 18-29.

Caballero, B. S., Teruel, G. P. J., \& Solano, M. P. (2014). Working Capital Management, Corporate Performance, and Financial Constraints. ScienceDirect. Journal of Business Research, 67(3), 332-338.

Claessens, S., Djankov, S., \& Klapper, L. (1999). Resolution of Corporate Distress in East Asia. Journal of Empirical Finance, 10(1), 1-33.

Darmawan, A., Supriyanto, J. (2018). The Effect of Financial Ratio on Financial Distress in Predicting Bankruptcy." Journal of Applied Managerial Accounting 2(1): 110-120.

Delavar, A., Kangarluei, S. J., \& Motavassel, M. (2015). Working Capital, Firms Performance and Financial Distress in Firms Listed in Tehran Stock Exchange (TSE). Indian Journal of Fundamental and Applied Life Sciences, 5(1), 2086-2093.

Fitriyah, I., Hariyati. (2013). Pengaruh Rasio Keuangan Terhadap Financial Distress Perusahaan Properti dan real Estate. Jurnal Dinamika Manajemen, 3(2), 101-109.

Hapsari, E. I. (2012). Kekuatan Rasio Keuangan dalam Memprediksi Kondisi Financial Distress Perusahaan Manufaktur di BEI. Jurnal Dinamika Manajemen, 3(2), 101-109.

Haq, S., Arfan, M., \& Siswar, D. (2013). Analisis Rasio Keuangan Dalam Memprediksi Financial Distress (Studi Pada Perusahaan Yang Terdaftar Di Bursa Efek Indonesia). Jurnal Akuntansi Pascasarjana Universitas Syiah Kuala, 2(1), 37-46.

Hazeem, B. A., Alaa, A. (2012). Predicting Financial Distress of Public Companies Listed in Amman Stock Exchange. European Scientific Journal, 8(15), 1-17.

Ibarra, V. C. (2009). Cash flow ratios: Tools for Financial Analysis. Journal of International Business Research, 8.

Kordestani, G., Biglari, V., \& Bakhtiari, M. (2011). Ability of Combinations of Cash Flow Components to Predict Financial Distress. Verslas: teorija ir praktika, 12(3), 277-285.

Kamaluddin, A., Ishak, N., \& Mohammed, N. F. (2019). Financial Distress Prediction Through Cash Flow Ratios Analysis. International Journal of Financial research, 10(3), 63-76.

Lakshan, A. M. I., Wijekoon, W. M. H. N. (2013). The Use of Financial Ratios in Predicting Corporate Failure in Sri Lanka. GSTF Journal on Business Review (GBR), 2(4), 37-42.

Matturungan, N. H., Purwanto, B., \& Irwanto. A. K. (2017). Manufacturing Company Bankruptcy Prediction in Indonesia With Altman Z-Score Model. Jurnal Aplikasi Manajemen, 15(1), 18-24. 
Meilinda, T., Muharam, H. (2012). Analisis Pengaruh Struktur Kepemilikan, Ukuran Perusahaan, Komisaris Independen, Likuiditas dan Leverage terhadap Terjadinya Kondisi Financial Distress (Studi pada Perusahaan Manufaktur yang Terdaftar di Bursa Efek Indonesia Tahun 2008-2010). Diponegoro Journal of Management, 1(1), 1-14.

Minnery, B. (2006). Don't Question the Importance of Cash Flow: Making a Profit Is the Goal but Day-to-Day Costs Must Be Met in Order to Keep a Business Afloat. Retrieved 28 $8^{\text {th }}$ May, 2010 from The Independent.com

Nurhayati, Mufidah, A., Kholidah, \& Asna N. (2017). The Determinan of Financial Distress of Basic Industry and Chemical Companies Listed in Indonesia Stock Exchange. Review of Management and Entrepreneurship, 1(2), 19-26.

Ong, S., Choong Yap, V., \& Khong, R. W. L. (2011). Corporate Failure Prediction: A Study of Public Listed Companies in Malaysia. Managerial Finance, 37(6), 553-64.

Platt, H. D., Platt, M. B. (2002). Predicting Corporate Financial Distress: Reflections on Choice-Based Sample Bias. Journal of Economics and Finance, 26(2), 184-99.

Rahmawati, A. I. E., Hadiprajitno, P. B. (2015). Analisis Rasio Keuangan Terhadap Kondisi Financial Distress pada Perusahaan Manufaktur yang Terdaftar di Bursa Efek Indonesia Tahun 2008-2013. Diponegoro Journal of Accounting, 4(2), 1-11.

Restianti, T., Agustina, L. (2018). The Effect of Financial Ratios on Financial Distress Conditions in Sub Industrial Sector Company. Accounting Analysis Journal, 4(1), 2533.

Rida, A., Khafid, M. (2014). Analisis Pengaruh Leverage, Ukuran Perusahaan, dan Voluntary Disclosure Terhadap Manipulasi Aktiva Riil. Accounting Analysis Journal, 3(3), 273281.

Sari, Y. P., Utami, M. (2009). Prediksi Financial Distress dengan Rasio Arus Kas. Manajemen dan Bisnis, 8(3), 192-204.

Sayari, N., Mugan, F. N Can Simga. (2013). Cash Flow Statement as an Evidence for Financial Distress. Universal Journal of Accounting and Finance, 1(3), 95-103.

Suwarno, A. E. (2004). Manfaat Informasi Rasio Keuangan dalam Memprediksi Perubahan Laba (Studi Empiris terhadap Perusahaan Manufaktur Go Public di Bursa Efek Indonesia. Jurnal Akuntansi dan Keuangan, 3(2), 127-52.

Thim, C. K., Choong, Y. V., \& Nee, C. S. (2011). Factors Affecting Distress: The Case of Malaysian Public Listed Firms. Corporate Ownership \& Volume, 8(4), 345-351.

Vieira, E. S., Pinho, C., \& Correia, C. (2013). Insolvency Prediction in the Portuguese Contruction Industry. Marmara Journal of European Studies, 21(2), 143-164.

Widati, L. W., Pratama, B. A. (2013). Pengaruh Current Ratio, Debt to equity Ratio, dan Return on Equity untuk Memprediksi Kondisi Financial Distress. Prosiding Seminar Nasional Multi Disiplin IImu \& Call for Papers UNISBANK.

Widarjo, W., Setiawan, D. (2009). Pengaruh Rasio Keuangan Terhadap Kondisi Financial Distress Perusahaan Otomotif. Jurnal Bisnis dan Akuntansi, 11(2), 107-119.

Wah, S., Mat, N. F., \& Yatim, P. (2001). Predicting Corporate Financial Distress Using the Logit Model: The Case of Malaysia. Asian Academy of Management Journal, 6(1), 4961.

Wongsosudono, Chrissa. (2013). Analisis Rasio Keuangan untuk Memprediksi Financial Distress pada Perusahaan Sektor Keuangan yang terdaftar di BEI. Bina Akuntansi-lbbi, 19(2).

Yadiati, W. (2017). The Influence of Profitability on Financial Distress: A Research On Agricultural Companies Listed In Indonesia Stock Exchange. Journal of Scientific \& Technology Research, 6(11), 233-37. 